\title{
Iron availability from peas (Pisum sativum) and bread containing added pea testa in rats
}

\author{
BY SUSAN J. FAIRWEATHER-TAIT AND A. J. A. WRIGHT \\ AFRC Food Research Institute, Colney Lane, Norwich NR4 $7 U A$
}

(Received 25 July 1984 - Accepted 4 October 1984)

\begin{abstract}
1. Iron retention in adult male rats given $3 \mathrm{~g}$ dried ground peas, immature and mature (Pisum sativum $\mathrm{cv}$ Dark-skin perfection) and leafless (Pisum sativum cv Filby), extrinsically labelled with $0 \cdot 25 \mu \mathrm{Ci}{ }^{50} \mathrm{Fe}$, was measured by whole-body counting. The Fe was less well absorbed $(P<0.01)$ from the mature peas $(0.251$ (SE $0 \cdot 021))$ than from the immature $(0.384$ (SE 0.032$)$ ) or leafless peas $(0.344$ (SE 0.026$)$ ).

2. The availability of $\mathrm{Fe}$ from the leafless peas was compared with that of defatted soya-bean flour by the same technique. Significantly more $\mathrm{Fe}(P<0.005)$ was retained from the pea flour $(0.471$ (SE 0.013$)$ ) than from the soya-bean flour $(0.377$ (SE 0.022$))$.

3. The effect of adding pea testa to bread $(97.6 \mathrm{~g} / \mathrm{kg}$ dry weight), as in the production of high-fibre white bread, on Fe availability was measured and compared with the availability of ferrous sulphate in young and adult male rats. There were no significant differences between the high-fibre and low-fibre breads in either age-group, although the older rats absorbed less $\mathrm{Fe}$ from all three sources. Retention from high-fibre bread, low-fibre bread and $\mathrm{FeSO}_{4}$ was as follows (mean with SE): young rats $0.452(0.037), 0.475(0.040) 0.541(0.032)$; mature rats $0.363(0.034)$, $0.366(0 \cdot 030), 0.471(0 \cdot 028)$.

4. It was concluded that the addition of pea testa to white bread does not have a detrimental effect on Fe availability. Immature and leafless peas appear to be a better source of available Fe than soya-bean flour, despite similar fibre levels, but with maturity the $\mathrm{Fe}$ in peas is rendered less available.
\end{abstract}

There is considerable interest in the development of plant proteins as an alternative to animal protein, the cost of which is steadily increasing. Special attention has been given to varieties of plants that can be grown in Britain, thus avoiding the need for costly imports. For example, a new variety of pea has been introduced, the leafless pea (Pisum sativum cv. Filby), which (as the name implies) has the obvious advantage of easier harvesting. In many instances, peas offer an alternative to imported soya beans and are being employed by the food industry in a variety of ways. One novel use is in the production of a high-fibre white bread by adding the seed-coat (testa) to white flour. This produces a loaf which has different sensory properties to that of wholemeal bread and is more acceptable to consumers who dislike the qualities of bran in wholemeal bread. With such products it should be possible to follow the UK Dietary Recommendations (Department of Health and Social Security, 1979) to increase dietary fibre intake without markedly altering the sensory quality of the diet. There is some concern, however, over the increasing use of vegetable proteins in food products with regard to the availability of iron and other minerals. The following study attempts to measure the availability of Fe in three types of pea flour, to compare peas with soya beans and to determine whether the addition of pea testa to white bread has an adverse effect on $\mathrm{Fe}$ availability.

\section{EXPERIMENTAL \\ Animals and diets}

In all experiments male Wistar rats were given a semi-synthetic control diet as described previously (Fairweather-Tait \& Wright, 1984) and trained to meal-feed once daily for 2 weeks before the test meal. After an overnight fast they were given the test meal as a paste made with distilled water extrinsically labelled with approximately $0 \cdot 25 \mu \mathrm{Ci}{ }^{59} \mathrm{Fe}$ (virtually carrier-free; Amersham International plc, Bucks). The control diet was returned to them 
not less that $3 \mathrm{~h}$ after consuming the test meal and from then until the end of the experiment they were allowed to feed ad lib.

The pea flours were prepared by freeze-drying the freshly harvested peas and grinding in an ultracentrifugal mill with a particle screen size of $1000 \mu \mathrm{m}$. The immature and mature peas were obtained from a white-flowered commercial variety used for freezing, canning and fresh sales, namely Pisum sativum cv. Dark-skin perfection. Some of the peas were harvested at the stage when they would be used for freezing (immature) and some were harvested whe 1 mature but undried. The leafless peas were harvested immature from the white-flowered Pisum sativum cv. Filby. Test meals for these three pea flours consisted of $3.0 \mathrm{~g}$ flour. In the second experiment, defatted soya-bean flour (British Soya Products, Puckeridge, Ware, Herts.) was given and, because the Fe content was approximately twice that of the leafless pea flour, only half as much soya bean was given as pea flour. The animals received $2.7 \mathrm{~g}$ soya-bean flour or $5.5 \mathrm{~g}$ pea flour in their test meal.

The bread containing pea testa $(97.6 \mathrm{~g} / \mathrm{kg}$ dry weight) was a high-fibre white loaf, and the low-fibre loaf was a standard white sliced bread. Both were prepared by a national baking company. The crusts were removed, the bread was dried for $24 \mathrm{~h}$ to constant weight at $60^{\circ}$ in a fan-oven and ground to a fine powder in a Moulinex coffee-grinder with a stainless-steel blade. The rats were given $3 \mathrm{~g}$ dried high-fibre or low-fibre bread made to a paste with approximately $5 \mathrm{ml}$ distilled water and labelled with ${ }^{59} \mathrm{Fe}$ as described previously. A third group was given a similar amount of $\mathrm{Fe}$ as in the bread test meal in the form of ferrous sulphate in $8 \mathrm{~g}$ starch-sucrose $(50: 50, \mathrm{w} / \mathrm{w})$ paste, extrinsically labelled with ${ }^{59} \mathrm{Fe}$. The experiment was carried out with young rats (approximately $100 \mathrm{~g}$ ) and then repeated with adult rats (approximately $300 \mathrm{~g}$ ).

\section{Whole-body counting}

The retention of Fe from the test meal was calculated by measuring the difference in ${ }^{59} \mathrm{Fe}$ content of the body immediately post-dosing and $7 \mathrm{~d}$ later when all the unretained Fe from the test meal had been excreted. This was done in a NE 8112 small-animal counter (Nuclear Enterprises, Edinburgh) as described previously (Fairweather-Tait \& Wright, 1984).

\section{Atomic absorption spectrophotometry $(A A S)$}

Diets were analysed for total Fe by ashing in silica crucibles at $480^{\circ}$ for $48 \mathrm{~h}$, taking the ash up in warm concentrated hydrochloric acid and diluting to an appropriate volume with distilled water. The $\mathrm{Fe}$ content of the resultant solution was measured by flame spectrophotometry using Pye Unicam PU 9000 AAS (Pye Unicam, Cambridge) with background correction, using standards supplied by the National Bureau of Standards (Office of Standard Reference Materials, Washington DC, USA).

\section{Dietary fibre}

The fibre contents of the pea flours and bread were determined by the method of Englyst et al. (1982).

\section{Phytate}

Phytates were extracted by a modification of the method of Tangkongchitr et al. (1981) by wet-ashing with sulphuric acid and hydrogen peroxide, and the phosphorus determined by the micromethod of the Association of Official Analytical Chemists (1980). Phytate was calculated as phytic acid.

\section{Statistical analysis}

Results from each experiment were compared using unpaired Student's $t$ test (Snedecor \& Cochran, 1973). 
Table 1. Mean weights $(g)$ and numbers of rats given test meals extrinsically labelled with ${ }^{59} \mathrm{Fe}$

(Mean values with their standard errors)

\begin{tabular}{|c|c|c|c|c|c|}
\hline \multirow{2}{*}{$\begin{array}{l}\text { Expt } \\
\text { no. }\end{array}$} & \multirow[b]{2}{*}{ Test meal } & \multirow{2}{*}{$\begin{array}{l}\text { Wt of test } \\
\text { meal }(g)\end{array}$} & \multicolumn{2}{|c|}{ Body-wt } & \multirow[b]{2}{*}{$n$} \\
\hline & & & Mean & $\mathrm{SE}$ & \\
\hline \multirow[t]{3}{*}{1} & $\begin{array}{l}\text { Immature peas } \\
\text { (Pisum sativum) }\end{array}$ & $3 \cdot 0$ & 292 & 6 & 13 \\
\hline & Mature peas & $3 \cdot 0$ & 290 & 8 & 14 \\
\hline & Leafless peas & $3 \cdot 0$ & 280 & 7 & 12 \\
\hline 2 & $\begin{array}{l}\text { Leafless peas } \\
\text { Defatted soya bean }\end{array}$ & $\begin{array}{l}5 \cdot 5 \\
2 \cdot 7\end{array}$ & $\begin{array}{l}203 \\
188\end{array}$ & $\begin{array}{l}4 \\
3\end{array}$ & $\begin{array}{l}12 \\
14\end{array}$ \\
\hline 3 & $\begin{array}{l}\text { High-fibre bread } \\
\text { Low-fibre bread } \\
\text { Ferrous sulphate* in } \\
\text { starch-sucrose paste }\end{array}$ & $\begin{array}{l}3 \cdot 0 \\
3 \cdot 0 \\
8 \cdot 0\end{array}$ & $\begin{array}{l}116 \\
118 \\
117\end{array}$ & $\begin{array}{l}3 \\
2 \\
3\end{array}$ & $\begin{array}{l}15 \\
15 \\
14\end{array}$ \\
\hline 4 & $\begin{array}{l}\text { High-fibre bread } \\
\text { Low-fibre bread } \\
\text { Ferrous sulphate* in } \\
\text { starch-sucrose paste }\end{array}$ & $\begin{array}{l}3 \cdot 0 \\
3 \cdot 0 \\
8 \cdot 0\end{array}$ & $\begin{array}{l}300 \\
297 \\
294\end{array}$ & $\begin{array}{l}4 \\
3 \\
3\end{array}$ & $\begin{array}{l}10 \\
14 \\
13\end{array}$ \\
\hline
\end{tabular}

* Weight of $\mathrm{FeSO}_{4} \cdot 7 \mathrm{H}_{2} \mathrm{O} 496 \mu \mathrm{g}$.

Table 2. Iron retention expressed as a proportion of the original dose, in groups of rats given test meals extrinsically labelled with ${ }^{59} \mathrm{Fe}$

(Mean values with their standard errors)

\begin{tabular}{|c|c|c|c|c|}
\hline \multirow{2}{*}{$\begin{array}{c}\text { Expt } \\
\text { no. }\end{array}$} & \multirow[b]{2}{*}{ Test meal } & \multirow{2}{*}{$\begin{array}{c}\text { Total Fe content } \\
(\mu \mathrm{g})\end{array}$} & \multicolumn{2}{|c|}{ Fe retention } \\
\hline & & & Mean & $\mathrm{SE}$ \\
\hline 1 & $\begin{array}{l}\text { Immature peas } \\
\text { (Pisum sativum) }\end{array}$ & 163 & $0.384^{\mathrm{a}}$ & 0.032 \\
\hline & Mature peas & 173 & $0 \cdot 251^{\mathrm{b}}$ & 0.021 \\
\hline & Leafless peas & 141 & $0 \cdot 344^{a}$ & 0.026 \\
\hline 2 & Leafless peas & 260 & $\begin{array}{l}0.471^{\mathrm{a}} \\
0.377^{\mathrm{b}}\end{array}$ & $\begin{array}{l}0.013 \\
0.02 ?\end{array}$ \\
\hline 3 & $\begin{array}{l}\text { High-fibre bread } \\
\text { Low-fibre bread } \\
\text { FeSO }_{4}\end{array}$ & $\begin{array}{r}78 \\
72 \\
100\end{array}$ & $\begin{array}{l}0.452^{\mathrm{a}} \\
0.475^{\mathrm{a}} \\
0.541^{\mathrm{a}}\end{array}$ & $\begin{array}{l}0.037 \\
0.040 \\
0.032\end{array}$ \\
\hline 4 & $\begin{array}{l}\text { High-fibre bread } \\
\text { Low-fibre bread } \\
\mathrm{FeSO}_{4}\end{array}$ & $\begin{array}{r}78 \\
72 \\
100\end{array}$ & $\begin{array}{l}0 \cdot 363^{a} \\
0 \cdot 366^{a} \\
0 \cdot 471^{b}\end{array}$ & $\begin{array}{l}0.034 \\
0.030 \\
0.028\end{array}$ \\
\hline
\end{tabular}

a, b For each experiment, values with different superscript letters were significantly different: Expt $1, P<0 \cdot 01$; Expt 2, $P<0.005 ;$ Expt 4, $P<0.025$.

\section{RESULTS}

The mean weights of the rats in the four experiments are shown in Table 1. Animals that ate less than two-thirds of the test meal were excluded from the experiment.

Mean Fe retention values are shown in Table 2. Animals fed on the mature peas retained significantly less $\mathrm{Fe}$ than those fed on either variety of immature peas $(P<0.01)$. The $\mathrm{Fe}$ in soya-bean flour was less well retained $(P<0.005)$ than that from the leafless peas. There 
Table 3. Iron $(\mu \mathrm{g} / \mathrm{g})$, fibre $(\mathrm{g} / \mathrm{kg})$ non-cellulosic polysaccharides $(\mathrm{g} / \mathrm{kg})$ and phytate $(\mathrm{mg} / \mathrm{g})$ levels of pea (Pisum sativum) flour, soya-bean flour and breads used for test meals in $\mathrm{Fe}$-availability studies

\begin{tabular}{|c|c|c|c|c|}
\hline Food & $\mathrm{Fe}$ & Fibre & $\begin{array}{l}\text { Non-cellulosic } \\
\text { polysaccharides }\end{array}$ & Phytate \\
\hline Immature peas & $54 \cdot 2$ & $171 \cdot 3$ & $93 \cdot 6$ & $3 \cdot 33$ \\
\hline Mature peas & $57 \cdot 8$ & $164 \cdot 5$ & $100 \cdot 7$ & $5 \cdot 29$ \\
\hline Leafless peas & $47 \cdot 1$ & $137 \cdot 6$ & $84 \cdot 5$ & $7 \cdot 68$ \\
\hline Defatted soya bean & $110 \cdot 9$ & $149 \cdot 4$ & $119 \cdot 1$ & 11.45 \\
\hline High-fibre bread & $26 \cdot 0$ & $105 \cdot 3$ & $55 \cdot 0$ & 0.99 \\
\hline Low-fibre bread & 23.9 & $37 \cdot 3$ & $32 \cdot 7$ & 1.42 \\
\hline
\end{tabular}

were no differences in Fe availability from the high-fibre bread with added pea testa or low-fibre bread when tested with young or adult rats. Not surprisingly, the young rats retained more $\mathrm{Fe}$, presumably due to requirements for growth, than the adult rats who were growing less quickly. There was a trend in the young rats towards greater Fe retention from the well-absorbed $\mathrm{Fe}$ salt $\mathrm{FeSO}_{4}$ than from the low- and high-fibre breads, but this was not significant. However, in the adult rats the retention from $\mathrm{FeSO}_{4}$ was significantly higher $(P<0.025)$ than from either bread.

The analytical values for the test meals are shown in Table 3.

\section{DISCUSSION}

There are a number of reports in the literature in which the absorption of Fe from soya-bean products has been shown to be low (Ashworth et al. 1973; Björn-Rasmussen et al. 1973; Cook et al. 1981) and others showing higher availability (Steinke \& Hopkins, 1978; Young \& Janghorbani, 1982). Although Fe availability from soya beans has been fairly extensively studied, very little work has been carried out on other legumes such as peas.

Various factors have been implicated as being totally or partially responsible for the low $\mathrm{Fe}$ availability in soya beans and other legumes. These include dietary fibre (Garcia-Lopez \& Wyatt, 1982) phytate (McCance et al. 1943) soya-bean protein (Schricker et al. 1982) and tannin (Disler et al. 1975; Rao \& Prabhavathi, 1982).

The fibre contents of the immature and the mature peas were similar, but the leafless peas contained slightly less fibre, more comparable to that found in defatted soya-bean flour. The addition of pea testa increased the fibre level of the bread quite considerably. Gillooly et al. (1984) showed that the only fibre constituents that inhibited $\mathrm{Fe}$ absorption were lignin and hemicellulose. There were only trace amounts of lignin present in the peas and soya-bean flour, but a high proportion of the dietary fibre was hemicellulose. However, as shown in Table 2, there is no evidence that fibre had any effect on $\mathrm{Fe}$ availability from peas, soya beans or bread. The phytate levels were higher in the leafless pea than in the other pea flours, and higher still in the soya-bean flour. The mature peas had slightly higher phytate $\mathbf{P}$ than the immature peas, as found also in soya beans (Forbes et al. 1983). Phytate P levels in the bread were low. Again there appeared to be no relation between phytate content and Fe availability. Most of the tannin in legumes is present in the seed-coat (Rao \& Prabhavathi, 1982) whereas the phytate resides mainly in the cotyledon (Griffiths, 1982). Thus, adding pea testa to bread should increase tannin but have no effect on phytate levels in the bread. However, white-flowered legumes (as used in these experiments) have very low levels of tannin compared with the coloured-flowered varieties (Deshpande et al. 1982). It is probable, therefore, that the addition of pea testa to white bread does not increase the tannin content to any significant extent. 
Fe retention from mature peas was significantly lower than from immature or leafless peas (Expt 1). The availability of $\mathrm{Fe}$ from soya beans was significantly lower than that from leafless peas (Expt 2). The values obtained for Fe retention from leafless peas were higher in Expt 2 than in Expt 1, but this is because the rats were younger in Expt 2 (see Table 1) and therefore capable of absorbing a higher proportion of Fe from the diet (Ruliffson \& Hopping, 1963). The differences in Fe availability between the pea and soya-bean flour cannot be explained in terms of variations in fibre or phytate levels, or both.

In Expts 3 and 4 there was no significant difference in Fe availability from low-or high-fibre white bread. The addition of pea testa had no detrimental effect on $\mathrm{Fe}$ availability despite increasing the fibre level of the bread. As explained previously, the phytate (and probably tannin) level would be unaffected by the addition of pea testa. In younger $(117 \mathrm{~g})$ rats (Expt 3) there were no significant differences in $\mathrm{Fe}$ absorption from either bread or $\mathrm{FeSO}_{4}$ but the older $(300 \mathrm{~g})$ rats (Expt 4$)$ absorbed $27 \%$ more $\mathrm{Fe}$ from $\mathrm{FeSO}_{4}$ than from the breads. In a similar experiment investigating the effect of wheat bran on Fe availability (FairweatherTait, 1982) the rats $\left(150 \mathrm{~g}\right.$ ) absorbed $33 \%$ more $\mathrm{Fe}$ from $\mathrm{FeSO}_{4}$ than from white bread containing a similar phytate level as wholemeal bread and $30 \%$ more than from wholemeal bread. It is clear therefore that, like wheat bran, pea testa does not have an adverse effect on Fe absorption when measured in rats. It appears that the high-fibre bread containing added pea testa had a similar $\mathrm{Fe}$ availability to white and wholemeal bread, and that the Fe was absorbed with an efficiency of about $70 \%$ of that of the well-absorbed $\mathrm{Fe}$ salt $\mathrm{FeSO}_{4}$. The $\mathrm{Fe}$ in immature or leafless pea flour was more readily absorbed than that in soya-bean flour, but when the peas mature the $\mathrm{Fe}$ is rendered less available.

Mr J. P. Tozer and Mrs Z. Piper played a major role in this work. The authors thank Mrs J. Cooke for assistance with the animals, Mr R. Faulks for analytical analyses and Miss R. Girdlestone for AAS.

\section{REFERENCES}

Ashworth, A., Milner, P. F. \& Waterlow, J. C. (1973). British Journal of Nutrition 29, 269-278.

Association of Official Analytical Chemists (1980). Methods of Analysis 13, 39.

Björn- Rasmussen, E., Hallberg, L. \& Walker, R. B. (1973). American Journal of Clinical Nutrition 26, $1311-1319$.

Cook, J. D., Morck, T. A. \& Lynch, S. R. (1981). American Journal of Clinical Nutrition 34, $2622-2629$.

Department of Health and Social Security (1979). Eating for Health. London: H.M. Stationery Office.

Deshpande, S. S., Sathe, S. K., Salunkhe, D. K. \& Cornforth, D. P. (1982). Journal of Food Science 47, 1846-1850.

Disler, P. B., Lynch, S. R., Charlton, R. W., Torrance, J. D. Bothwell, T. H. Walker, P. B. \& Mayet, F. (1975). Gut 16, 193-200.

Englyst, H., Wiggins, H. S. \& Cummings, J. H. (1982). Analyst, London 107, 307-318.

Fairweather-Tait, S. J. (1982). British Journal of Nutrition 47, 243-249.

Fairweather-Tait, S. J. \& Wright, A. J. A. (1984). British Journal of Nutrition 51, 185-191.

Forbes, R. M., Parker, H., Kondo, H. \& Erdman, J. W. (1983). Nutrition Research 3, 699-704.

Garcia-Lopez, S. \& Wyatt, C. J. (1982). Journal of Agricultural and Food Chemistry 30, 724-727.

Gillooly, M., Bothwell, T. H., Charlton, R. W., Torrance, J. D., Bezwoda, W. R., MacPhail, A. P., Derman, D. P., Novelli, L., Morrall, P. \& Mayet, F. (1984). British Journal of Nutrition 51, 37-46.

Griffiths, D. W. (1982). Journal of the Science of Food and Agriculture 33, 847-851.

McCance, R. A., Edgecombe, C. N. \& Widdowson, E. M. (1943). Lancet ii, 126.

Rao, B. S. N. \& Prabhavathi, T. (1982). Journal of the Science of Food and Agriculture 33, 89-96.

Ruliffson, W. S. \& Hopping, J. M. (1963). American Journal of Physiology 204, 171-175.

Schricker, B. R., Miller, D. D. \& Van Campen, D. (1982). Journal of Nutrition 112, 1696-1705.

Snedecor, G. W. \& Cochran, W. G. (1973). Statistical Methods; 6th ed., p. 599. Ames, Iowa: Iowa State University Press.

Steinke, F. H. \& Hopkins, D. T. (1978). Journal of Nutrition 108, 481-489.

Tangkongchitr, V., Seib, P. A. \& Hoseney, R. C. (1981). Cereal Chemistry 58, 226-228.

Young, V. R. \& Janghorbani, M. (1982). Journal of Plant Foods 4, 57-73. 